\title{
Doing Well By Doing Good In The Community: Evidence From Some South African Small Businesses
}

Professor D. Y. Dzansi, Central University of Technology, Free State, South Africa

\begin{abstract}
Researchers and policy makers worldwide are convinced that only clear empirical evidence of the economic benefits of business social responsibility (BSR), rather than normative assertions, can motivate small businesses enough to accept and adopt it as an integral business practice. Unfortunately, empirical research so far has yielded mixed results, such that smaller businesses are right to be skeptical about adopting BSR. This paper reports the findings of empirical research on patterns of BSR engagement practices and growth in firms' sales and gross profit among small and micro enterprises (SMMEs) in a South African setting. This is to determine how a small firm's economic performance varies (if at all) with the degree of its BSR performance and the kind of BSR activity it engages in. The results suggest a high degree of BSR activity among firms with substantial portions of profit dedicated to BSR. However, contrary to expectations, very weak (minor) link was found between BSR performance and economic performance among the sample of small businesses on some but not all dimensions of BSR considered in the study. Nonetheless, it is recommended that managers and owners of small businesses be encouraged to adopt and practice BSR. Even if they do not do so for economic reasons, they would be right to do so to 'atone' for the widely acknowledged detrimental impacts of business on society.
\end{abstract}

Keywords: Financial Performance; Business Social Responsibility; South Africa; Business Case; Bottom Line; Key Stakeholders

\section{INTRODUCTION}

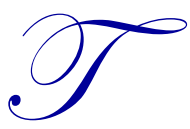

his paper concerns small businesses pursuing BSR activities in South Africa. The research is applied in nature and as such bears the characteristics of typical applied business research - it is intended to find practical solution to a specific business problem for small businesses. It is therefore appropriate to begin with a description and discussion of the problem facing small businesses and the context in which it is being studied.

\section{Problem Context}

To begin, it is worth considering the following statement credited to New York Life (2013): No one has to tell anyone that small businesses are the economic backbone of our communities. It is self-evident. This statement speaks volumes about the growing importance and attention that has been paid to small businesses in recent times. The above statement and the growing importance of small businesses is a truism in South Africa's rural communities and perhaps other parts of the world with similar conditions where, on an aggregate basis, small businesses are regarded as the mainstay of the economy, largely because of the absence of large companies (Dzansi, 2011). However, this author also reported that small rural businesses, on an individual basis, have not been contributing as much as would be liked because they do not grow in terms of production or employment capacity. With this limitation in mind, Dzansi $(2004 ; 2011)$ suggested that small rural businesses engage in BSR to enhance their ability to improve the economies of their local or rural communities where there are no large businesses. From this perspective, it becomes not only necessary but crucial to motivate small business owners and managers to engage in BSR. Echoing the same sentiment, Epstein and Roy (2003) stated that it is only by making the business case for engaging in BSR that small business owners/managers will be motivated enough to accept BSR as a sound business imperative and truly integrate it into their business strategies. 
It is important that the business case for BSR engagement is made to small companies by evidencing the measurable payoff of such initiatives. Small businesses have resource constraints that naturally compel their owners and managers to ensure that they commit their scarce resources appropriately. BSR must therefore be seen to make absolute or at least considerable economic sense. Whilst empirical research may have provided increasing evidence to larger corporates of the measurable payoff of BSR initiatives (Carroll and Shabana, 2010), unfortunately, to date, this evidence appears to be divided on the economic justification of smaller businesses engaging in socially responsible activities. In fact, Carroll and Shabana (2010) cite Roman et al. (1999) to classify the differing empirical evidence of BSR payoff into three categories namely (i) a positive link; (ii) a negative link; (iii) no link - a classification that shows divergent evidence on the economic justification for BSR performance. Even normatively, the jury remains divided on the topic. It is however heartening that even in the midst of this unresolved measurable payback for BSR engagement, there are reported signs of small businesses in South Africa actively participating in BSR activities (e.g. Okyere, 2013). What is left now is to demonstrate that such BSR activity brings with it measurable payoff.

Although the literature is replete with considerable conceptual and empirical work on the business/society relationship, an extensive literature review using Google search revealed that most of these studies have focused more on large organisations (e.g. Davis, 1960; Carroll 1979; Wartick and Cochran, 1985; Wood, 1991; Wingard, 2001, just to mention a few) rather than smaller ones; and in terms of small-business BSR research, most of the literature draws on the European context. There is therefore a gap in the literature regarding the empirical business case for smaller businesses engaging with BSR in the developing-country context, especially South Africa. Thus questions like "do small businesses in the developing-country context really benefit tangibly from engaging in BSR policies, activities and practices; and how do they benefit tangibly from engaging in BSR policies, activities and practices" remain unanswered.

\section{Problem Statement}

In light of the problem discussed above, background research was required to explore this largely neglected area in the field of business/social research - the case for BSR among small businesses in the rural developing country context. Although there are a handful of performance indicators to choose from, this study explored patterns of BSR practices, sales, and growth in gross profit among small businesses in a rural South African setting to determine the relationship (if any) between small businesses' engagement with BSR and their economic performance. As will be seen later, these two performance indicators are the measures used in the adopted conceptual framework guiding the study.

\section{Objectives of the Study}

The objectives of the study were to determine the relationship (if any) between:

(i) BSR performance and sales growth;

(ii) BSR performance and gross profit growth.

\section{Structure of the Paper}

The paper commences with a summary of the relevant literature that was reviewed. It begins by examining definitions of the concept of BSR, leading to an operational definition. This is followed by a discussion of the theoretical lens though which this paper views BSR. Next, the drivers of BSR in small businesses are discussed in order to understand the most common kinds of BSR activities for small businesses and why they engage in them. Following this, the extant literature on the small firm/social responsibility business case is reviewed. Finally, the conceptual framework for the empirical study is presented. 


\section{LITERATURE REVIEW}

\section{Defining BSR}

In spite of its long history (Carroll and Shabana, 2010), which can be traced as far back as to the 1950s (Madrakhimova, 2013), to date no single universally accepted definition can be found for BSR. This situation is perhaps due to the number of labels that have been used to refer to the same concept. These include but are not limited to: corporate citizenship (CC), corporate accountability (CA), corporate sustainability (CS), and of course, corporate social responsibility (CSR), people planet and profit (PPP), triple bottom line (TBL), and sustainable development (SD) just to mention a few. The plethora of labels for BSR leads one to first consider the small matter of appropriate terminology before defining it in the context of small businesses.

Whilst there is no doubt that CSR is the most commonly used term for the concept, the continued use of 'corporate' is problematic as it suggests 'a big business only' connotation at the exclusion of smaller companies (Dzansi, 2004). However, as Kruse (2014) among other writers have pointed out, small businesses are equally if not more involved in promoting the business/society agenda. In fact, Kruse (2014) and Larson (2014) acknowledge that small businesses have a long and proud tradition of making a difference, particularly at the local level through giving to the needy. Dzansi (2004) is therefore right in concluding that the term business social responsibility, with its acronym BSR, is more appropriate as it accommodates all sizes of business - the same sentiment recently shared by Ladzani and Seeletse (2012).

For the purposes of this paper, the more popular and adaptive definitions of BSR that seem to capture the essence of what the concept stands for - especially for small businesses - are considered. According to the European Commission (EC) (2014), BSR is about companies giving generously to local communities because of the negative impact of their operations on society. This negative-externalities sentiment was first proposed by Kapp (1978) who, in his book The Social Costs of Business Enterprise, argued that because businesses force negative externalities such as air and water pollution, disease and many others upon the communities where they conduct their business, they ought to devote some of their income to voluntary causes in those communities as a form of compensation. Not surprisingly, the EC (2014) advocates that businesses integrate social, environmental, ethical, human rights and consumer concerns into their business operations and core strategy in close collaboration with their stakeholders. From this perspective, societal and environmental welfare as well as ethics, human rights, consumerism and stakeholder concepts - all sustainability issues - are important aspects of BSR. Smith (2011) defines BSR as "a business system that enables the production and distribution of wealth for the betterment of its stakeholders through the implementation and integration of ethical systems and sustainable management practices". This definition does not differ much from the EC's (2014) version, which also focuses on the same issues of ethics, stakeholders and sustainability. Dzansi and Pretorius (2009) state that in the context of small businesses, BSR can be defined as "a firm's commitment to operating a business in an economically sustainable manner while at the same time recognizing the interests of its other stakeholders (customers, employees, business partners, local communities, society at large) over and above what the law prescribes". This definition is adopted in this paper due to the commonalities it has with most definitions reviewed and the fact that it is supposedly meant for small businesses, which is the focus of the present research. Adopting this definition enables us to use Dzansi's (2009) SMME-BSR framework (see Figure 1). It also implies acceptance of the stakeholder theory as a foundation on which BSR is built.

\section{Stakeholder Theory in the BSR Domain}

The stakeholder theory, as applied in business, involves a three-legged approach to conducting business whereby the day-to-day business practices ensure sustainability for the owners (the economic goal of any business), the environment and society at large. Kapp (1978) was one of the pioneers to justify this approach to business management by arguing that in their daily operations to create economic value for owners, businesses unintentionally create undesirable and sometimes unintended detrimental consequences in the geographical areas in which they operate; for that, they need to compensate society. In other words, business operations affect other parties ('stakeholders' in management parlance) such as the environment and inhabitants in the communities where they are located. Today, the stakeholder approach transcends this earlier compensatory approach to include the 
belief that a business' BSR activities will result in a win-win situation. This is where both community welfare and business performance are improved when a firm considers and integrates other stakeholder interests alongside those of its owners in their day-to-day operations (Freeman, 1984).

There is a general consensus in the literature that a stakeholder, as used in the business sense, refers to any individual or group who is affected by and can affect the outcomes or objectives of a business (Freeman, 1984; Laczniak and Murphy, 1993; Reed, 2002; Mukasa, Kim and Lim, 2015). There is also consensus that stakeholders of a business can be placed into two broad categories, namely primary and secondary stakeholders based on their capacity to influence business outcomes (Laczniak and Murphy, 1993; Okyere, 2013). The management literature affirms that a firm's key primary stakeholders include its customers, investors, government, suppliers, and employees (Fombrun, 1996; Reed, 2002; Okyere, 2013).

\section{Does the Stakeholder Theory Make Any Business Sense?}

Whilst at face value the stakeholder theory might be viewed as detrimental to owner interests, as suggested by Friedman (1970), Davies (1973) and Hayek (1969), the literature suggests otherwise. Instead, researchers including Laczniak and Murphy (1993), McWilliams and Siegel (2001), Reed (2002), Margolis, Elfenbein, and Walsh (2007), Carroll and Shabana (2010), Dzansi (2004), Okyere (2013) and many others - argue that the stakeholder theory actually works to the benefit of the owner interests. Reed (2002) sums up the complementary nature of both shareholder and the stakeholder objectives in three points namely (i) all primary stakeholders have an economic stake in the firm; (ii) the economic activity of the firm contributes to 'the common good' of the stakeholders; and (iii) stakeholder focus leads a firm to gain 'authenticity', that is, 'licenses to operate in the community'. Therefore, the stakeholder view of the firm does not contradict the economic view but rather encompasses it. Thus, "there is some sense in asking businesses to support local community values and initiatives" (Reed, 2002, in Dzansi and Pretorius, 2009). That is, from the stakeholder perspective, it makes much economic sense for small businesses to engage in BSR.

\section{Economic Justification for BSR Engagement}

Arguments and evidence regarding the economic justification for BSR are mixed. In terms of normative assertions, some authors, starting with Friedman (1970), believe that engaging in BSR depletes shareholder wealth. Some empirical studies seem to support this view. For example, Sauer (1997), Kneader, Gray, Power, and Sinclaire (2001), and Bauer, Günster, and Otten (2003) could not find any relationship between the two variables in their studies. From this perspective, it is argued that if a business engages in BSR, it does so solely because it is the right thing to do and not because of any direct economic gains.

On the other hand, Kruse (2014) and many others believe that BSR is economically beneficial to businesses. Kruse (2014) and the likeminded argue that engaging in BSR goes beyond the altruistic purpose of simply feeling good as a result of helping a worthy cause. Rather, according to Kruse (2014), BSR can raise the profile of a business, reinforce employee morale, as well as foster teamwork and collaboration that enhances employees' on-the-job performance. Richard Branson, the billionaire businessman, claims to have used BSR to grow his then-emerging (small) business Virgin Records. Branson (2013) attests that financially backing a student advisory centre in London in the early 1970s helped his then-growing small business to keep in touch with customers' concerns and problems. According to New York Life (2013), small businesses are duty-bound to give back to and get involved in their communities because such acts help build customer loyalty, increase visibility and eventually positively impact the bottom line since small business owners' involvement in their community's activities gives potential customers another reason to visit the business. This means that BSR engagement by small businesses can lead to customer loyalty and eventual profitability.

Some empirical studies support the positive impact of BSR on businesses' economic performance. Orlitzky, Schmidt, and Reynes (2003) analysed several studies that examine the relationship between BSR and firm performance and concluded that it pays to be socially responsible. Wingard (2001) also found a positive correlation between environmental responsibility and the performance of South African listed companies; i.e., the higher the environmental responsibility of a company is, the higher its financial performance. Another study at Harvard 
University found that 'stakeholder-balanced' companies showed four times the growth rate and eight times the employment growth of companies that are 'shareholder-only' focused. Although these studies have largely focused on big companies, they show that a business can behave in a socially responsible manner and still increase shareholder wealth. There is therefore very strong economic motivation for small businesses to engage in BSR.

\section{The Conceptual Framework for the Economic Benefit of BSR by Small Businesses}

This study adopted Dzansi's (2009) framework for investigating BSR in SMMEs (see Figure 1). Dzansi (2009) contended that although the general conceptualisation recognises four major stakeholders for business, in reality, as far as smaller organisations are concerned, environmentalism does not matter so much. Thus, for SMMEs, Dzansi (2009) contended that employees, customers and the local trading community are the key stakeholders. They went on to suggest that engagement in BSR activities focused on these key stakeholders (labelled dimensions) results in both positive organisational and other stakeholder benefits. Dzansi goes on to distinguish between organisational benefits that are tangible (sales growth and profit growth) and those that are intangible (see Figure 1). This paper focuses on the tangible organisational outcomes, namely sales growth and profit growth.

Figure 1. Components of Small business-BSR interface (adapted from Dzansi 2009).

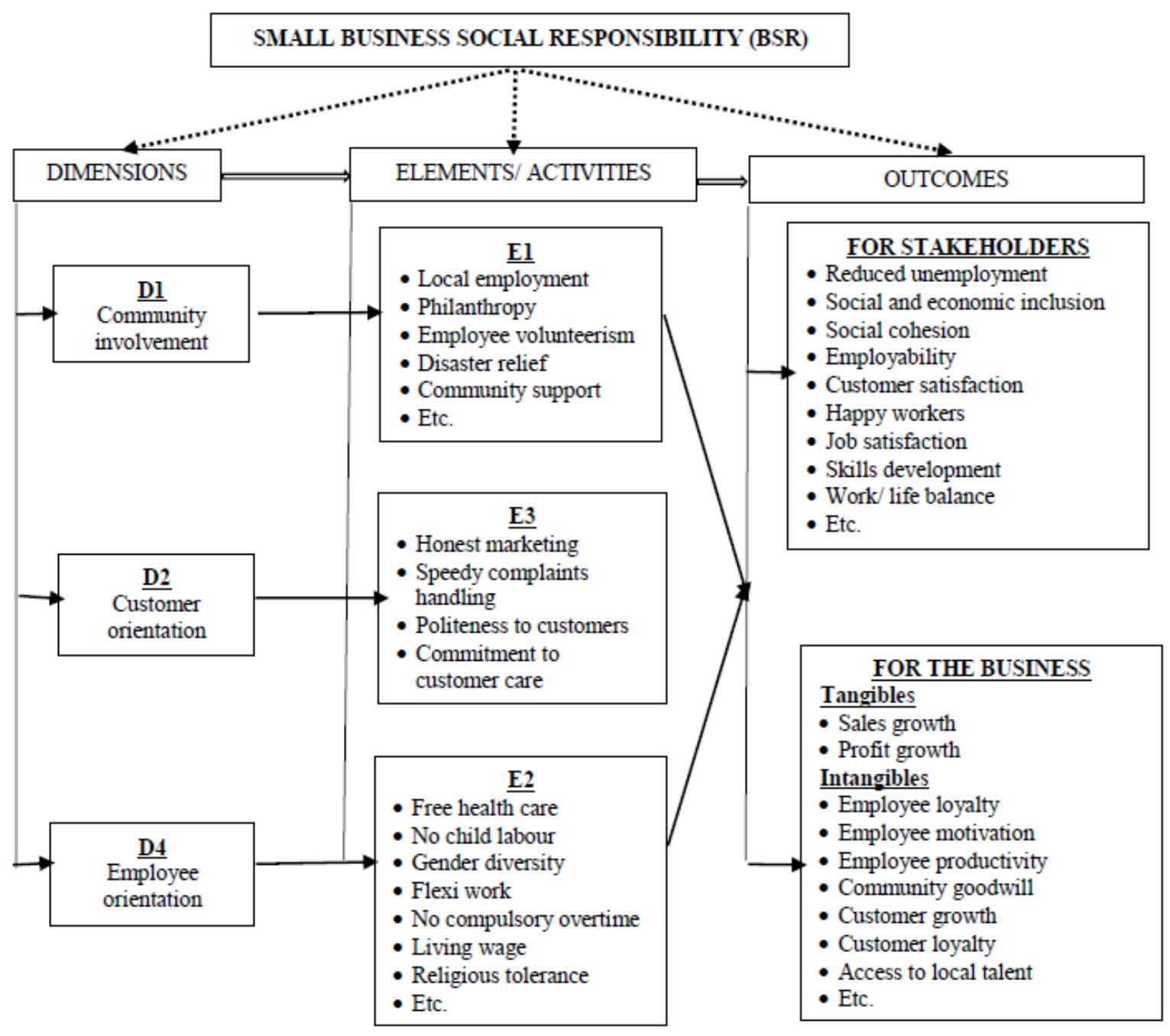




\section{Research Philosophy and Design}

\section{METHOD}

The study was conducted using the quantitative mode of inquiry, which involves adherence to the objectivist ontology and the positivist epistemology. The target population was small businesses from a rural part of Taung in the North West province of South Africa. The study covered only micro and small businesses, meaning businesses that employ no more than 50 full-time workers in addition to the owner/manager. None of the businesses qualified to be classified as a medium enterprise. The actual population size was difficult to determine because of the informal nature of most of the businesses, coupled with the fact that no reliable database exists in the area. In any case, it was always going to be difficult to obtain a reliable existing sample frame for the study given the high attrition rate in the South African small business sector (Dzansi, 2011) - a problem also acknowledged by Curran and Blackburn (2001). The participants in the study consisted of the owners/managers of 350 randomly selected small businesses from a self-compiled sample of 1,127 identifiable businesses with fixed business premises.

\section{Data Collection Including Instrument Credibility}

Dzansi's (2004) Small Enterprise Social Responsibility Inventory (SESRI) was used. The questionnaires were directed to the participants face-to-face. This consisted of five-point Likert-style structured questions where respondents chose the degree to which they agree or disagree with a statement.

Every study has credibility issues concerning the validity and reliability of the measurement instruments used. The SESRI has been tested for validity and, with a Cronbach's alpha well above 0.70 , was found to be a valid instrument for measuring BSR in small businesses (see Dzansi, 2004; Dzansi and Pretorius, 2009). According to Dzansi (2004), content validity could also be assured through extensive literature review on various measures of BSR in SMMEs, leading to the identification of measurement questions deemed to adequately measure all dimensions of BSR in SMMEs. Also, in line with Dzansi (2004), the questionnaires were circulated amongst notable researchers in the field of BSR for their comments and approval. Further, to minimise respondent errors, which are often the source of threats to reliability (Leedy and Ormrod, 2012), only willing participants were included in the sample.

\section{Data Analysis}

The data was analyzed using the statistical software SAS. The analysis included both descriptive statistics (such as frequency tables and means) and inferential statistics. Based on the frequency distribution that showed normal distribution and the fact that the participants were randomly selected, the parametric analytic technique ANOVA (with $F$ statistic the preferred choice among the various ANOVA types) was carried out to determine the relationship between BSR performance and sales growth and gross profit growth. Whilst ANOVA indicates whether or not there are statistically significant differences between means, it does not necessarily show whether there are differences between all means nor the nature of such differences (Cohen, Manion and Morrison, 2011). As suggested by the same authors, to find out the nature of the differences, a post-hoc test must follow. In the current study, whilst statistically significant differences suggest relationships between BSR performance and sales growth and gross profit growth, how that relatedness pans out must be established. This was done using Tukey's post-hoc test, as suggested by Cohen, Manion and Morrison (2011).

\section{RESULTS}

\section{Response Rate}

Of the targeted sample of 350 SMMEs, 314 attended a face-to-face interview, thus yielding a response rate of $89.7 \%$. Contrary to the normal low response rate associated with small business research in the South African rural context (Dzansi, 2004; Agbobli, 2012; Arko-Achemfuor, 2012; Amoakoh, 2013; Okyere, 2013), this high rate is the result of the painstaking and patient questionnaire distribution and collection approach that required field workers to visit participants repeatedly. Another contributing factor to the high response rate was that the field workers were recruited from within the community so that they could easily interact with participants, hence ensuring active cooperation from participants. 


\section{Selected Demographics}

Table 1 presents selected demographic statistics relevant to the paper. Table 1 shows that the majority (over $70 \%$ ) of the SMMEs investigated reported increasing sales growth. The majority (about $70 \%$ ) reported gross profit growth similar to the growth in sales reported above. These figures indicate a thriving business environment that should encourage others to consider self-employment as a career option. On the other hand, it is also an indication that these businesses are being run in an astute manner. Table 1 indicates that all of the businesses contribute some percentage of their profit to BSR, which is encouraging. These findings are similar to those of Okyere (2013) who, in a study on small businesses in the Botshabelo industrial estate in the Free State province of South Africa, found a high degree of financial outlay on BSR-related activities. Taken together, these research results imply that BSR may no longer be restricted to big business, and is being taken seriously by small businesses in South Africa, especially those located in rural communities where BSR efforts are most needed to address socio-economic problems.

Table 1. Selected demographics

\begin{tabular}{|c|c|c|}
\hline BSR expenditure as \% of pre-tax profit & Frequency & Percentage \\
\hline ( & 68 & $21.66 \%$ \\
\hline $3-4 \%$ & 108 & $34.39 \%$ \\
\hline $5-6 \%$ & 71 & $22.61 \%$ \\
\hline $7-10 \%$ & 67 & $21.34 \%$ \\
\hline Total & 314 & $100 \%$ \\
\hline \multicolumn{3}{|l|}{ Sales growth } \\
\hline Decreasing & 27 & $8.60 \%$ \\
\hline No change $(0 \%)$ & 55 & $17.52 \%$ \\
\hline Increasing (1-10\%) & 73 & $23.25 \%$ \\
\hline Increasing $(11-20 \%)$ & 91 & $28.98 \%$ \\
\hline Increasing ( $21 \%$ and over $)$ & 68 & $21.65 \%$ \\
\hline Total & 314 & $100 \%$ \\
\hline \multicolumn{3}{|l|}{ Gross profit growth for the past 3-5 years } \\
\hline Decreasing & 25 & $7.96 \%$ \\
\hline No change $(0 \%)$ & 63 & $20.07 \%$ \\
\hline Increasing $(1-10 \%)$ & 70 & $22.29 \%$ \\
\hline Increasing (11-20\%) & 95 & $30.25 \%$ \\
\hline Increasing ( $21 \%$ and over) & 61 & $19.43 \%$ \\
\hline Total & 314 & $100 \%$ \\
\hline
\end{tabular}

\section{Analysis of Variance (ANOVA) of Mean Scores for BSR Performance}

Table 2 presents the mean scores of BSR performance and the results of a one-way ANOVA test on these means - a statistical technique that analyses variability in data in order to infer inequality or otherwise among population means.

The scale mean for community practice was 3.78; that of customer-related BSR activities was 3.97; and that of employee practices was 4.4443 (see Table 2). These are all above the median value of 3 on the five-point Likert scale, indicating that on average, the small businesses surveyed to a large extent engage in community, customer and employee-related BSR activities. These are similar to the findings made by Okyere (2013).

Table 2. Analysis of variance

\begin{tabular}{cl|llrrrr}
\hline $\begin{array}{c}\text { Independent } \\
\text { variable }\end{array}$ & $\begin{array}{c}\text { Mean } \\
\text { score }\end{array}$ & Dependent variables & DF & $\begin{array}{c}\text { Sum of } \\
\text { squares }\end{array}$ & $\begin{array}{c}\text { Mean } \\
\text { squares }\end{array}$ & F & P \\
\hline $\begin{array}{c}\text { Community } \\
\text { practices }\end{array}$ & \multirow{2}{*}{3.78} & Sales growth & 4 & 1.09650952 & 0.27412738 & 1.24 & 0.2927 \\
\hline $\begin{array}{c}\text { Customer } \\
\text { practices }\end{array}$ & \multirow{2}{*}{3.97} & Gross profit growth & 4 & 1.40300197 & 0.85075049 & 3.86 & $0.0046^{* *}$ \\
\hline $\begin{array}{c}\text { Employee } \\
\text { practices }\end{array}$ & \multirow{2}{*}{4.44} & Gales growth & 4 & 0.25862242 & 0.06465561 & 0.92 & 0.4517 \\
& & Gross profit growth & 4 & 0.20723584 & 0.05180896 & 0.74 & 0.5664 \\
\hline
\end{tabular}

**Significant at both .01 and .05 level of significance

*Significant at .05 level of significance 
While the small businesses surveyed reported high levels of BSR activity on all three dimensions of BSR (see Table 2), the ANOVA output revealed mixed results as far as significant differences are concerned (see Table 2). Table 2 shows that there are no statistically significant differences in sales growth or gross profit margin based on customeroriented BSR practices $\left(F_{4}=0.92, p>.01\right.$ and .05 for sales growth, and $F_{4}=0.74, p>.01$ and .05$)$, and that there are no significant differences in sales growth based on community-oriented BSR practices $\left(F_{4}=1.24, p>.01\right.$ and .05 ). These statistics can be interpreted to mean that (i) both sales growth and gross profit growth do not depend on customer-related BSR practices; and that (ii) sales growth does not depend on community-related BSR practices. These findings could be regarded as a setback for those who want to use a positive relationship between these variables to motivate BSR uptake among small businesses.

There were, however, some encouraging findings. In Table 2, gross profit growth shows significant differences based on community practices at both .05 and .01 levels of significance $\left(F_{4}=3.86, p<.05\right.$ and .01$)$. This is an indication that community BSR practices influence gross profit growth. Secondly, both sales growth and gross profit growth vary significantly at the .05 level of significance based on employee-oriented BSR practices $\left(F_{4}=3.05, p<\right.$ .05 and $F_{4}=3.31, p<.05$ respectively), which indicates that employee-related BSR practices influence both sales growth and gross profit growth.

In accordance with Cohen, Manion and Morrison (2011), the nature of these differences was further explored using the Tukey post-hoc (follow-up) test. Table 3 illustrates the results of this test, which was only conducted on groups that showed statistically significant differences (see Table 2). In Table 3, the means (horizontal) with different alphabetic indicators $(a$ and $b$ ) comply with Tukey at $p<.01$. This means that score means with the same alphabetic labels are not significantly different from one another while score means with different alphabetic labels differ significantly from one another at .01 significance level. The figures in Table 3 therefore mean that community and employee related practices influence economic performance of the businesses. For employee BSR practices, both sales growth and gross profit growth can be placed into two groups, namely decreasing and no growth or increasing. It can therefore readily be discerned from Table 3 that higher mean scores for employee-related BSR activities correspond to increasing or at least no change in both sales and gross profit growth. This implies a somewhat positive relationship between employee-related BSR practices and firm performance, as measured by sales growth and gross profit growth. As can be seen in Table 3, interpretation for community-related BSR practices is rather less straightforward. At best it can be said that there is a positive relationship between community-related BSR practices and gross profit growth; however, this is only evident when mean BSR performance score is at least equal to 3.99 .

These findings are very interesting. They suggest that it takes more community-related BSR activities to yield positive economic benefits than employee-related BSR activities would take to yield the same economic benefits. This interpretation makes a great deal of sense when one considers the classification of stakeholders according to the importance of the influence they have on business outcomes (see Reed, 2002; Dzansi, 2011; Okyere, 2013). From this perspective, it would make a great deal of sense for small businesses to prioritize employee-related BSR activities.

Table 3. Nature of differences in sales growth and gross profit growth based on BSR performance

\begin{tabular}{|c|c|c|c|c|c|c|}
\hline BSR Activity & Statistic & Decreasing & No change & $\begin{array}{c}\text { Increasing } \\
1-10 \%\end{array}$ & $\begin{array}{c}\text { Increasing } \\
11-20 \%\end{array}$ & $\begin{array}{c}\text { Increasing } \\
21 \%+ \\
\end{array}$ \\
\hline \multicolumn{7}{|l|}{ Sales growth } \\
\hline \multirow{2}{*}{ Employee practices } & Mean & $3.84 \mathrm{~b}$ & $4.40 \mathrm{a}$ & $4.51 \mathrm{a}$ & $4.59 \mathrm{a}$ & $4.45 \mathrm{a}$ \\
\hline & $\mathrm{SD}$ & 0.93 & 0.75 & 0.60 & 0.44 & 0.58 \\
\hline \multicolumn{7}{|l|}{ Gross profit growth } \\
\hline \multirow{2}{*}{ Community practices } & Mean & $3.68 \mathrm{~b}$ & $3.78 \mathrm{~b}$ & $3.73 \mathrm{~b}$ & $3.74 \mathrm{~b}$ & $3.99 \mathrm{a}$ \\
\hline & SD & 0.33 & 0.29 & 0.33 & 0.36 & 0.34 \\
\hline \multirow{2}{*}{ Employee practices } & Mean & $3.72 \mathrm{~b}$ & $4.46 \mathrm{a}$ & $4.47 \mathrm{a}$ & $4.57 \mathrm{a}$ & $4.50 \mathrm{a}$ \\
\hline & SD & 0.87 & 0.72 & 0.61 & 0.47 & 0.55 \\
\hline
\end{tabular}

All means (horizontal) with different alphabetic indicators comply with a Tukey at $\mathrm{p}<0.01$. 


\section{LIMITATIONS}

Firstly, the methodology requires self-evaluation by the respondents, which may not always be objective. However, it was assumed that the respondents were honest enough not to exaggerate their responses and hence provide some level of realistic reporting. The second limitation of the study is the absence of any questions concerning environmental issues. Thirdly, the limited geographical scope, small sample size, and the small rural setting of the study require caution when generalizing from the results.

\section{CONCLUSIONS}

From the literature, it is evident that BSR has become a prevalent business issue and has been firmly on the research agenda in recent times. It is also clear that there is still a lot of work to do in trying to convince smaller businesses to devote some of their already-limited resources to BSR, largely because extant research has not proven the BSR business case sufficiently enough and because the results of the current empirical research have not helped either. The results of the current research show higher-scale means than the median value of 3 for BSR (see Table 2), which means that the small businesses surveyed take BSR seriously. This implies that BSR may no longer be reserved for big business and is being taken seriously by small businesses in South Africa. The results in Tables 2 and 3 show that BSR activity yields more positive economic payoffs when directed at employees than when directed at other stakeholders such as the general community and customers.

\section{RECOMMENDATIONS}

Although no statistically significant positive link was statistically established between BSR engagement and firm performance as measured by gross profit and sales growth, the fact that most $(70 \%)$ of the businesses reported significant profit and sales growth is of practical significance. Policy makers can therefore use this finding as a basis upon which to motivate small businesses to engage in BSR.

Also, notwithstanding the lack of statistically significant support for measurable payoff on certain BSR dimensions in this research, it is recommended that managers and owners of small businesses be encouraged and convinced to adopt and practice BSR, even if not for economic reasons, to simply 'atone' for the widely acknowledged detrimental impacts of business on society. The positive relationship between some BSR activities and economic payoff can be used to strengthen any such campaign.

As discussed above, it would make a great deal of sense for small businesses to prioritize employee-related BSR activities since the economic payoff appears greater for this dimension of BSR than for others.

On the research front, it is possible that the basis of comparison might have influenced the results. A different result might have been achieved had the comparison been between gross profit and sales growth over the last five years versus proportions of gross profit committed to BSR cause over the same period. Better still, instead of self-reported data, documentary analysis might yield a different result. Future researchers are therefore encouraged to pursue these two research agendas.

\section{AUTHOR BIOGRAPHY}

Dennis Yao Dzansi, Ph.D. (Entrepreneurship); MBA; MA (Higher Education Studies), is the Head of Department of Business Support Studies and Associate Professor of Project Management at the Central university of Technology, Free State, South Africa. His research interests include business social responsibility, business ethics, business strategy, entrepreneurship and small business management, organisational behaviour, project management and organisational justice. E-mail: ddzansi@cut.ac.za

\section{REFERENCES}

Agbobli, E.K. (2012). The influence of entrepreneurial and market orientations on small scale agricultural enterprises in the Vryburg region. Unpublished PhD thesis, Central University of Technology, Free State, South Africa. 
Amoakoh, E.O. (2013). The status and influence of marketing research on the economic performance of hair salons in the Bophirima region. Unpublished Masters dissertation, Central University of Technology, Free State, South Africa.

Arko-Achemfuor, A. (2012). Interaction between ethnicity and entrepreneurship in South Africa. Case study of Naledi Municipality. Unpublished PhD thesis, Central University of Technology, Free State, South Africa.

Bauer, R., Günster, N. \& Otten, R. (2003). Empirical evidence on corporate governance in Europe: the effects on stock return, firm value and performance. Working paper, September.

Branson, R. (2013). Richard Branson on Community Building to Grow Your Business. Entrepreneur. http://www.entrepreneur.com/article/226219. Retrieved on 20 October 2014.

Carroll, A.B. (1979). A three-dimensional conceptual model of corporate social performance. Academy of Management Review, 4, 497-505.

Carroll, A.B. \& Shabana, K. (2010). The business case for CSR: Review of concepts, research and practice. International Journal of Management Review, 12(1), 85-105.

Cohen, L., Manion, L. \& Morrison, K. (2011). Research methods in education. $7^{\text {th }}$ Edition. London: Sage.

Davis, K. (1960). Can business afford to ignore social responsibilities? California Management Review, 2, 70-76.

Davies, K. (1973). The case for and against business assumption of social responsibility. Academy of Management Journal, $16(2), 312-322$.

Dzansi, D.Y. (2004). Social responsibility of SMMEs in rural communities. Unpublished PhD thesis, University of Pretoria, Pretoria, South Africa.

Dzansi, D.Y. \& Pretorius, M. (2009). The development and structural confirmation of an instrument for measuring the social responsibility of small and macro business in the African context. Social Responsibility Journal, 5(2), 450-463.

Dzansi, D.Y. (2011). Social responsibility of small businesses in a typical rural African setting: Some insights from a South African study. African Journal of Business Management, 5(14), 5710-5723.

Dzansi, D.Y. \& Hoeyi, P. (2013). An Economic Perspective on Small Business Social Responsibility. Journal of Social Science, 37(1), 93-104.

Epstein, M.J. \& Roy, M. (2003). Making the Business Case for Sustainability: Linking Social and Environmental Actions to Financial Performance. Journal of Corporate Citizenship, 9, 79-96.

European Commission. (2011). A renewed EU strategy 2011-14 for corporate social responsibility. [http://eurlex.europa.eu/LexUriServ/LexUriServ.do?uri=COM:2011:0681:FIN:EN:PDF]. Retrieved on 19 September 2013.

European Commission. (2014). Corporate Social Responsibility (CSR). [http://ec.europa.eu/enterprise/policies/sustainablebusiness/corporate-social-responsibility/index_en.htm]. Retrieved on 11 May 2015.

Fombrun, C.J. (1996). Reputation: Realizing value for corporate image. Boston, MA: Harvard Business School Press.

Friedman, M. (1970). The social responsibility of business is to increase its profits. New York Times Magazine, New York.

Freeman, R.E. (1984). Strategic Management: A Stakeholder Approach. Massachusetts: Pitman Publishing Inc.

Hayek, F.A. (1969). The corporation in a democratic society, In H. Ansoff, H. Business Strategy. Harmondsworth: Penguin Books.

Kapp, K. W. (1978). The Social Costs of Business Enterprise. London: Spokesman.

Kneader, N., Gray, R.H., Power, D.M. \& Sinclair, C.D. (2001). Evaluating the performance of ethical and non-ethical funds: a matched pair analysis. Working paper.

Kruse, J. (2014). Make your business part of the community. Corridor Business Journal. January 6-12, 15-16. [http://www.corridorbusiness.com/consulting/make-your-business-part-of-the-community/]. Retrieved on 12 May 2015.

Laczniak, G.R. \& Murphy, P.E. (1993). Ethical Marketing Decisions: The Higher Road. Boston: Allyn and Bacon.

Ladzani, M.W. \& Seeletse, S.M. (2012). Business social responsibility: how are SMEs doing in Gauteng, South Africa? Social Responsibility Journal. 8(1), 87-99.

Larson, M. (2014). Make your business part of the community. Mason County Press. [http://www.masoncountypress.com/2014/06/11/make-your-small-business-part-of-the-community/]. Retrieved on 22 September 2014.

Leedy, P.D. \& Ormrod, J. E. (2012). Practical research. Planning and design. $8^{\text {th }}$ Edition. New Jersey: Pearson Merrill Prentice Hall.

Madrakhimova, F.S. (2013). Evolution of the concept and definition of corporate social responsibility. Global Conference on Business and Finance Proceedings, 8(2), 113-118.

Margolis, J.D., Elfenbein, H.A. \& Walsh, J.P. (2007). Does it pay to be good? A meta-analysis and redirection of research on the relationship between corporate social and financial performance. Working Paper, Harvard Business School, Boston, MA.

McWilliams, A. \& Siegel, D. (2001). Corporate social responsibility: A theory of the firm perspective. Academy of Management Review, 26(1), 117-127.

Mukasa, K.D. Kim, K. \& Lim, H. (2015). How Do Corporate Social Responsibility Activities Influence Corporate Reputation? Evidence From Korean Firms. Journal of Applied Business Research, 31(2), 383-395.

New York Life. (2013). How to get your business involved in the community: giving back and gaining loyalty. [http://www.newyorklife.com/learn-and-plan/how-to-get-your-business-involved-in-community-by-giving-back-gainingloyalty]. Retrieved on 05 April 2015.

Okyere, F. (2012). Social responsibility in the SMMEs of the Botshabelo industrial estates. Unpublished Masters dissertation, 
Central University of Technology, Free State, South Africa.

Orlitzky, M. Schmidt, F.L. \& Reynes, S.L. (2003). Corporate Social and Financial Performance: a meta-analysis. Journal of Organisational Studies, 24(3), 403-441.

Reed, D. (2002). Employing normative stakeholder theory in developing countries: a critical theory perspective. Business and Society, 41(2), 166-207.

Sauer, D.A. (1997). The impact of social-responsibility screens on investment performance: evidence from the Domini 400 Social Index and Domini Equity Mutual Fund. Review of Financial Economics, 6(2), 137-49.

Smith, E.R. (2011). Defining Corporate Social Responsibility: A Systems Approach for Socially Responsible Capitalism. A Masters Dissertation. University of Pennsylvania. http://repository.upenn.edu/cgi/viewcontent.cgi?article=1009andcontext=od_theses_mp. Retrieved on 19 March 2015.

Wartick, S.L. \& Cochran, P.L. (1985). The evolution of the corporate social performance model. Academy of Management Review, 10, 765-766.

Wingard, H. C. (2001). Financial Performance of Environmentally Responsible South African Listed companies. PhD Thesis. Pretoria: University of Pretoria. 


\section{NOTES}

